\title{
Perceptions of HIV/AIDS testing among urban and rural African American church members
}

\author{
Roblena E. Walker, PhD ${ }^{1}$ \\ ${ }^{1}$ EMAGAHA, INC., Walden University
}

\begin{abstract}
Background: The prevalence of the human immunodeficiency virus (HIV) continues to affect African Americans (AA) disproportionately. The purpose of this mixed methods study, guided by the health belief model, was to examine associations linking church and ambient social environment with knowledge and perceptions of HIV/AIDS testing amongst urban and rural AA church members.
\end{abstract}

Methods: Multiple regressions and t tests were used to compare perceptions of HIV/AIDS testing and knowledge of HIV/AIDS among 236 participants selected from two AA churches located in a large city $(\mathrm{n}=122)$ and in a rural town $(\mathrm{n}=$ 114) in the Southern U.S.

Results: The quantitative findings indicated that the urban participants reported significantly higher rates of testing than the rural participants, but the groups had equally high HIV knowledge and positive perceptions of HIV/AIDS testing. In-depth, individual interviews (24 urban; 24 rural) were conducted to gain a better understanding of the factors that contribute to perceptions of HIV/AIDS testing and knowledge of HIV/AIDS. Transcripts were axially coded for a priori themes and then analyzed for emergent categories of responses. These interviews indicated that the participant's perceptions of HIV/AIDS testing were in general, not influenced by the church and that there were no noticeable distinctions regarding why HIV/AIDS testing was sought. The combined results of this study suggested that the churches surveyed were not promoting HIV/AIDS awareness and that the participants felt that the church should do more as it relates to HIV/AIDS.

Conclusions: Since the AA church plays an important role in the lives of many AAs, it potentially can, particularly in rural areas, bring forth social change by advocating HIV/AIDS testing and prevention efforts in order to reduce the rate of HIV infections.

Key words: HIV, AIDS, perception Black church

\section{INTRODUCTION}

HIV/AIDS is the greatest threat to health worldwide (CDC, 2015b; NIH, 2009; Levine, 2007). In 1981, the HIV/AIDS epidemic swept across the United States and since has disproportionately affected women, men who have sex with men, youth, and minorities, particularly African Americans (AAs) (National Institute of Allergy and Infectious Diseases (NIAID), 2010. In 2013, an estimated 47,352 individuals were infected with HIV, and 26,688 were diagnosed with AIDS (CDC, 2015b). Because of insufficient diagnosis and reporting of individuals unknowingly infected with HIV, the overall prevalence of HIV cannot be measured (Centers for Disease Control and Prevention (CDC), 2012). The lack of awareness of one's serostatus and unwittingly transmitting the HIV virus is thought to be a result of deficient HIV testing. The CDC (as cited in NIAID, 2009) recommended that HIV testing be administered during routine medical visits in order to make persons aware of their status and to provide counseling on safe-sex practices and avoidance of high-risk behaviors. To shed light on the barriers driving the high rates of HIV/AIDS amongst AAs, it is necessary to understand how perceptions of HIV/AIDS influence HIV/AIDS testing rates amongst AAs.

Over the last 3 decades, the AIDS epidemic has severely influenced the lives of many. Although all Americans are directly or indirectly affected by this epidemic, AAs are disproportionately affected (CDC, 2015). Contrasted to other racial/ethnic groups, HIV/AIDS rates have been higher among AAs (CDC, 2015a; Whitmore, Satcher, \& Hu, 2005). From 2008 to 2010, new HIV infections among AA women decreased by 21\%; however, AA women still account for $13 \%$ of all new HIV infections and $64 \%$ of all new infections among women (CDC, 2015b). Representing only $12.3 \%$ of the total population, AAs have acquired more than $50 \%$ of all HIV/AIDS diagnoses (Hall, Hutchinson, \& Sansom, 2008). In 2002, the CDC estimated that 1 in 50 AA men and 1 and 60 AA women were infected with HIV (Adedeji, Titilayo, Joseph, \& Mainza Lukobo-Durrell, 2009). Even though AA men and women are disproportionately affected by HIV/AIDS, the disparity is greater for AA men (CDC, 2015b; Whitmore, Satcher, \& $\mathrm{Hu}, 2005)$. 
From slavery to freedom, the AA church has been, for many AAs, a place of comfort and sustainability. Guided by a spiritual flame, the AA church has served a site for restoration and a place of worship, but, most of all, it has offered a sense of belonging. For many, the AA church provides a foundation and coping strategies in times of trouble and despair (McKoy \& Peterson, 2006; Nunn, Cornwall, Thomas, Waller, Friend, Broadnax, \& Flanigan, 2013; Smith, Simmons, \& Mayer, 2005). Often lauded for charitable works in their respective communities, many AA churches, however, do not discuss topics such as homosexuality and sexual morality (Krakauer, Phil, \& Newberry, 2007). Although AA churches provide an ideal setting for discussions on a variety of topics, including religious education, spiritual formation, finances, and even recurrent diseases (Billingsley, 1992; Miller, 2007; Nunn et al., 2013; Williams, 1972), within these churches, there is a lack of discussions about diseases transmitted through sex. Although the AA church is involved in shaping cultural norms and attitudes about sexuality and serves as a social and spiritual outlet for AAs, openly discussing topics such as HIV/AIDS presents a challenge. As a means of focusing on prevention of HIV/AIDS and behavioral modifications amongst AAs, the church should delve into the context of the disease, both from a scientific (knowledge-based) and social aspect (Moore, 2003).

\section{PURPOSE}

There are relatively few investigations on the perceptions of HIV/AIDS amongst AA church members. Previous studies have indicated that targeting nontraditional entities, such as the AA church, can be effective in (a) encouraging community awareness, (b) correlating to mental and physical health, (c) cultivating awareness of safe sex, and (d) encouraging regular HIV/AIDS testing amongst AAs (Billingsley, 1992; Coleman, 2003; Daniels \& Wimberly, 2004; Jarama, Belgrave, Bradford, Young, \& Honnold, 2007; Miller, 2007; Williams, 1972).

To understand the problem and implement strategies for dealing with it, it is essential to identify the level of HIV knowledge and/or HIV testing behavior amongst AA church members. Using the AA church to provide educational teachings on HIV/AIDS may decrease negative perceptions of HIV testing amongst AAs. Further, examining differences in perceptions of HIV/AIDS testing amongst urban and rural AA church members may aid in solving the problem. The present study examined the perceptions (fears and beliefs) of HIV/AIDS testing and knowledge and risky sexual behavior(s) amongst urban and rural AA church members.

\section{METHODS}

This research utilized quantitative methodology to examine the associations between HIV/AIDS knowledge and education level, positive or negative perceptions of HIV/AIDS testing and education level, and positive or negative perceptions of HIV/AIDS testing amongst urban and rural AA church members. Qualitative methodology, by use of in-depth individual interviews, explored the source of the urban and rural AA church members' perceptions of HIV/AIDS testing. These interviews provided insight into the perceptions of HIV testing amongst urban and rural AA church members.

\section{Research Design and Approach}

This research design utilized both quantitative and qualitative methodologies, while allowing the concurrent collection of data on the perceptions and beliefs of the participants. The study design employed a QUAN + QUAL design (Johnson \& Onwuegbuzie, 2004), which allowed for equal emphasis on the quantitative and qualitative findings. This research sought to identify factors that influenced urban and rural AA church members' perceptions of HIV/AIDS testing. A mixed-method design was used. Additionally, urban and rural AA church members' perceptions of HIV/AIDS testing were examined in their natural setting, the AA church. A multiple-case study qualitative research design was employed.

In Phase 1, the quantitative research took place within the urban and the rural AA churches. Information was collected via surveys. The research questions that were used to guide the quantitative portion of this study were as follows:

\section{Does HIV/AIDS knowledge differ among urban and rural AA church members?}

\section{$\mathrm{H}_{\mathrm{o}}$ : There is no difference in HIV/AIDS knowledge among urban and rural AA church members.}

\section{Do perceptions of HIV/AIDS testing vary among urban and rural AA church members?}

\section{$\mathrm{H}_{\mathrm{o}}$ : There is no variance of perceptions of HIV/AIDS testing among urban and rural AA church members.}

3. Is there a correlation between knowledge of HIV/AIDS and perceptions of HIV/AIDS testing amongst urban and rural AA church members? Does this correlation differ among urban and rural AA church members?

\section{$\mathrm{H}_{\mathrm{o}}$ : There is no correlation between knowledge of HIV/AIDS and perceptions of testing among urban and rural AA church members.}

In Phase 2, research also took place within the urban and rural AA churches, using the qualitative case study design, which allowed for an examination of the source of perceptions of HIV/AIDS testing amongst these church members. This research design used in-depth individual interviews of randomly selected participants chosen from a list of active members provided by each church. At the conclusion of each interview, participants were provided information on HIV/AIDS testing sites in their community. The research questions that were used to guide the qualitative portion of this study were as follows:

1. What influence does the church and the messages received in the church have on the perceptions of HIV/AIDS testing amongst urban and rural AA church members? 
2. What factors lead to low rates of HIV/AIDS testing amongst urban and rural AA church members?

\section{Setting and Sample}

The urban AA (Baptist) church was located in DeKalb County, GA, within the metro Atlanta area. The church has a membership of over 10,000. As a bible-based church, it has established several ministries, including Worship, Evangelism, Fellowship, Discipleship, and Ministry. The rural AA (AME) church, located in a rural setting, Lee County, SC, ministers to 500 members. This church has incorporated several ministries, including the Christian Education Ministry, the Sons of Allen and the Daughters of Sarah Ministry, the Women's Missionary Society, the Young People's Division, the Music Ministry, and other discipleship ministries. Currently, neither church has an HIV/AIDS ministry.

The participants in the study sample were geographically spread across the states of Georgia and South Carolina, were associated with multiple socioeconomic structures, and attended the selected churches on a regular basis. This study included a combination of homogeneous and heterogeneous sampling. The use of homogeneous sampling, which involves individuals with similar subcultures, allowed for in-depth exploration of the topic by focusing on the perceptions of HIV/AIDS testing that are characteristically similar amongst participants. The employment of homogeneous sampling provided a common variable among participants, which was church location. Heterogeneous sampling was also useful in allowing a complex phenomenon to shed light on different perspectives for those with similar experiences, behaviors, and/or perceptions.

For this research, a power analysis was conducted use of the technique described by Cohen (1992) and calculated using G*Power. A medium effect size (ES) of 0.50 was selected to distinguish differences between two independent sample means. Based upon the ES, $\alpha$ was set at 0.05 and yielded an $N$ of 105 targeted participants per group, for a total $N$ of 210. Among the targeted sample for each church, 122 urban and 114 rural church participants were given a survey, and a subsample of 24 participants from each church were randomly selected to participate in the survey as well as in the in-depth individual interview. The targeted sample size yielded a $95 \%$ confidence level, resulting in $95 \%$ power.

Upon the recommendations of the pastors of each church, ministries that consisted of persons best suited and who met requirements for inclusion in this study were targeted. The targeted participants were members in good standing and were active within the ministry and the church as a whole. Further, each church provided a list of members who were actively involved in church activities and attended church services on a regular basis for inclusion in the in-depth interview phase. To eliminate bias, persons from this list were selected randomly. This research targeted AA men and women aged $18-45$ years old, the age group with the highest prevalence of HIV (CDC, 2015b).

\section{Data Collection and Analysis}

Data were collected by a variety of methods that established trustworthiness of the study. Survey-questionnaires and interview(s) gathered data from participants relating to perceptions of HIV/AIDS testing. Demographic data were collected from each participant and used to describe the population. The consent form served as the only document to connect the participant's real name to their chosen pseudonym. Access to the demographic data was restricted to the researcher. To determine the positive and negative perceptions of HIV/AIDS testing amongst urban and rural AA church members, the questionnaire(s) contained a series of questions that asked each participant about their HIV/AIDS testing history, HIV/AIDS knowledge, educational experience, experience with sex education taught in the church, and sexual experience.

Semi-structured, one-on-one interviews were conducted with subsets of the targeted samples, which were selected from the list of active members provided by each church. Participants were contacted via e-mail or phone call to schedule a date, time, and location for the individual interview. Written permission/consent was retrieved from each participant prior to conduct of the study. Each interview took at least 60 minutes.

The interview form was utilized to guide the interview. There were 12 questions to evaluate further the perceptions of HIV/AIDS testing. These questions were developed to determine the source and/or connection among the AA church and the perceptions of HIV/AIDS testing among urban and rural AA church members.

Both qualitative and quantitative data were analyzed to examine the relationship between the AA church and the source of positive or negative perceptions of HIV/AIDS testing among urban and rural AA church members. Qualitative data were analyzed using the grounded theory approach. The interviews were transcribed, and themes and/or descriptions were derived from a thematic analysis. The categories were derived from the open coding phase of the study, which considered the perceptions of HIV/AIDS testing amongst urban and rural AA church members. The coding phase began with preset themes that enabled the researcher to categorize data responses. The text was searched for data that matched the emerging themes.

The survey results were entered into a Microsoft Excel spreadsheet. The resulting compilation showed responses grouped into rows representing each respondent and by columns representing each question asked in the survey. Finally, tables were compiled showing the results of the data analysis and how these data related to each of the research questions.

Analysis of qualitative data. Tape-recorded interviews from each participant were transcribed and analyzed. Observations were noted in a reflexive journal. The transcription of each interview was sent via email to the interviewee to verify proper transcription. This procedure improved the credibility and strength of the transcribed data. The interviewee was asked to respond within five days of receipt of the email regarding any suggested transcription modification. Qualitative analysis of the key points from each individual interview took place from the first 
transcription until the final transcription. Each transcription was compiled into a table format that linked and identified the factors (e.g., church attendance, HIV/AIDS prevention methods) that influenced perceptions of HIV/AIDS testing amongst urban and rural AA church members. Based upon the factors and the responses from each participant, a thematic analysis emerged, and a theory was generated from the data.

Analysis of quantitative data. Correlational statistics were utilized to assess relationships for multiple variables and to describe relationships between the variables. Bivariate correlations were incorporated to gain strengths among the relationships of the variables and to determine associations. Multivariate extensions to the bivariate correlations were incorporated, if necessary. Three hypotheses were tested:

\section{There is no difference in HIV/AIDS knowledge among} urban and rural AA church members.

2. There is no variance of perceptions of HIV/AIDS testing among urban and rural AA church members

3. There is no correlation between knowledge of HIV/AIDS and perceptions of HIV/AIDS testing among urban and rural AA church members.

Quantitative data were measured using the HIV-Knowledge Questionnaire (HIV-K-Q) adapted from Carey, MorrisonBeedy, \& Johnson (1997). The HIV-K-Q assessed independent variables related to knowledge about HIV transmission (e.g., vaginal, anal, and oral sexual intercourse; blood products and needle sharing; perinatal), nontransmission of HIV (e.g., saliva, insect bites, touching, sharing food), effective risk reduction strategies (e.g., male and female condom, abstinence, monogamy), ineffective risk reduction strategies (e.g., douching, birth control pills, vaccine), prevention methods and consequences of infection (e.g., asymptomatic period, treatment, disease course) (Carey, Morrison-Beedy, \& Johnson, 1997). Use of this instrument reflected the conceptualization of the phenomenon and was consistent with the purpose of the study. The HIV-K-Q questionnaire was self-administered and took only 10 minutes to complete. Knowledge of HIV/AIDS among the urban and rural AA church members was scored by use of a mean number of correct answers, which facilitated interpretation of the HIV knowledge-based questions. Possible scoring ranged from $0-45$, with questions marked as "I Don't Know" being scored as 0 . Higher scores were associated with higher knowledge of HIV and positive perceptions of HIV/AIDS testing. Statistical analyses were performed through the use of $t$ tests.

To understand in more detail the source of the positive or negative perceptions of HIV/AIDS testing among urban and rural AA church members, in-depth individual interviews were used. Subjective scoring was utilized to note the number of positive perceptions of HIV/AIDS testing. Positive responses included, but were not limited to, "HIV testing is important," "becoming tested allows one to know his/her status," "engaging in risky sexual behaviors increases one's risk for HIV infection," and "lack of awareness increases risky sexual behaviors." The source(s) of the positive or negative perceptions included, but were not limited to, the urban and/or rural AA churches, their environment, family, and/or friends.

Inferential statistical procedures, such as multiple regression analyses, were used for comparisons of variables amongst the urban and rural AA church members. The $p$ values were calculated and used to assess whether the effect of religious affiliation/location on perceptions of HIV/AIDS testing was statistically significant. Univariate analyses were performed to assess the percentage of urban and rural AA church members who reported certain perceptions of HIV/AIDS testing. Multivariate analyses were used to control for potentially confounding variables. Data from the qualitative and quantitative findings were integrated by way of complementation. As a final point, tables showing the results of the data analysis and how the data correlated with each of the research questions were compiled.

\section{RESULTS}

A total of 122 urban AA church members $(N=122$; males $n$ $=67,54.9 \%$; females $n=55,45.1 \%)$ and a total of $114(N$ $=114)$ rural AA church members $(N=114$; males $n=55$, 48.2\%; females $n=59,51.8 \%$ ) completed the quantitative surveys. A subsample of 24 urban and 24 rural church participants, randomly selected, completed the qualitative in-depth interviews. To ensure validity, credibility, reliability, and trustworthiness of the survey and interview instruments used in the study, each of the instruments was pilot-tested with 10 participants, 5 men and 5 women $(n=$ 20), from each church who did not participate in the actual research study. Inter-rater reliability testing with the pilot testers was conducted. Follow-up interviews took place with each pilot participant after they had completed the pilot testing. After the interviews were completed, it was determined that no adjustments to the instrument were necessary. The purpose of the pilot study was to develop and test the data collection instruments.

There was no significant difference in demographics between the urban and rural church members (Table 1).

Age

The average age among the urban and rural participants was 32.2. Among the urban church participants, the age was 32.8 years and, for the rural church participants, 31.6 years. Ages ranged between 18 and 45 years, indicating homogeneous representation for the entire sample set for both groups.

\section{Education}

Most urban $(73.8 \%)$ and rural $(75.4 \%)$ church participants had completed high school or a bachelor's level education; $23 \%$ of the urban and $18.5 \%$ of the rural church participants completed graduate or professional degree programs.

\section{Marital Status}

Most urban $(67.2 \%)$ and rural $(66.7 \%)$ church participants were not married (i.e., single, divorced, or widowed). 


\section{Annual Income}

Survey options were given in $\$ 10,000$ increments up to $\$ 100,000$. More urban $(55.8 \%)$ and rural $(42.1 \%)$ church participants indicated an annual income of $\$ 30,000$ to $\$ 59,000$. Only 4 participants (two from each group) indicated annual incomes between $\$ 100,000$ and $\$ 150,000$, with none indicating more than $\$ 150,000$. There was nearly equal representation among the urban and rural church participants regarding annual income; hence the income between both groups did not differ significantly.

\section{Employment}

Most urban $(89.3 \%)$ and rural $(86.0 \%)$ church participants were employed, which included categories related to contract or seasonal work (Table 1).

\section{Church Participation}

Most urban $(80.3 \%)$ and rural $(80.8 \%)$ church participants were 'fairly active' or 'extremely active' in their church.

\section{Self-Reported HIV Knowledge Ratings}

When asked about their knowledge of HIV/AIDS, participants reported having 'some knowledge' (urban, $54.1 \%$; rural, $47.4 \%$ ) or being 'very knowledgeable' (urban, $23.0 \%$; rural, $17.5 \%$ ).

\section{Self-Reported HIV Testing}

Most the urban $(77.0 \%)$ and rural $(60.5 \%)(p=0.006)$ church participants indicated they had been tested for HIV/AIDS. The probability value, indicated a statistically significant difference in rates of testing among the urban and rural participants. Table 2 presents data on the percentages of HIV/AIDS testing, the perceptions of HIV/AIDS testing, and the HIV/AIDS status among urban and rural church participants. In this table, significant differences among the urban and rural church participants are noted with an asterisk (*).

\section{Source of HIV Testing Perceptions}

Most urban (62.3\%) and rural (55.3\%) participants indicated that they had positive perceptions of HIV/AIDS testing. There was a significant difference in perceptions based on education between the urban and rural church participants. Over half $(53.3 \%)$ of the urban participants indicated that their source of HIV/AIDS testing did not stem from education, compared to $(39.5 \%)$ for the rural participants. Most urban $(55.7 \%)$ and rural $(50.0 \%)$ church participants indicated their perceptions of HIV/AIDS testing were primarily based on their knowledge of HIV/AIDS. Only $21.3 \%$ of urban and $20.2 \%$ of rural church participants, however, indicated that their perceptions of HIV/AIDS testing were based on the church.

Table 1a. Urban and Rural Demographics - Age, Education, Marital Status, Annual Income, Employment Status, Church Participation, \& Self-Reported HIV/AIDS Knowledge ( $\mathbf{N}=\mathbf{2 3 6})$

\begin{tabular}{|l|c|c|c|}
\hline & Urban & Rural & $\mathbf{p}$ \\
\cline { 2 - 4 } & $\mathbf{( N = 1 2 2 )} \%$ & $\mathbf{( N = 1 1 4 )} \%$ & \\
\hline Age - Mean & 32.8 & 31.6 & 0.637 \\
\hline Education & & & \\
\hline No Diploma & 3.3 & 6.1 & \\
\hline High School/Equivalent & 14.8 & 9.6 & \\
\hline Some College/Associates Degree & 21.3 & 27.2 & \\
\hline Bachelors Degree & 37.7 & 38.6 & \\
\hline Masters Degree/Professional & 22.2 & 17.6 & \\
\hline Doctorate Degree & 0.8 & 0.9 & \\
\hline Marital Status & & & 0.929 \\
\hline Married & 32.8 & 33.3 & \\
\hline Not Married & 67.2 & 66.7 & \\
\hline Annual Income & & & 0.295 \\
\hline$<\$ 10 \mathrm{~K}$ & 4.1 & 13.2 & \\
\hline \$10-29K & 25.5 & 28.1 & \\
\hline \$30-59K & 55.8 & 42.1 & \\
\hline$>\$ 60 \mathrm{~K}$ & 14 & 16.6 & \\
\hline Employment Status & & & 0.249 \\
\hline Employed & 89.3 & 86 & \\
\hline Unemployed & 10.7 & 14 & \\
\hline
\end{tabular}




\begin{tabular}{|c|c|c|c|}
\hline \multirow[b]{3}{*}{ Church Participation } & Urban & Rural & $\mathbf{p}$ \\
\hline & $(\mathrm{N}=122) \%$ & \multirow[t]{2}{*}{$(\mathrm{N}=114) \%$} & \multirow[b]{2}{*}{0.420} \\
\hline & & & \\
\hline Inactive & 3.3 & 4.4 & \\
\hline Barely Active & 16.4 & 14 & \\
\hline Fairly Active & 31.1 & 40.4 & \\
\hline Extremely Active & 49.2 & 40.4 & \\
\hline \multicolumn{4}{|c|}{ Self Reported - HIV/AIDS Knowledge } \\
\hline No Knowledge & 6.6 & 8.8 & 0.213 \\
\hline Very Little Knowledge & 16.4 & 26.3 & \\
\hline Some Knowledge & 54.1 & 47.4 & \\
\hline Very Knowledgeable & 23 & 17.5 & \\
\hline
\end{tabular}

Self-Reported HIV Status. There were 12 (9.8\%) urban and $6(5.3 \%)$ rural church participants who indicated that they were HIV-positive. Of the urban participants, 3 did not answer this question. A total of $58(47.5 \%)$ urban and
$42(36.8 \%)$ rural church participants knew someone who is HIV positive.

\begin{tabular}{|c|c|c|c|}
\hline & Urban & Rural & $\mathbf{p}$ \\
\hline & $(\mathrm{N}=122) \%$ & $(\mathrm{~N}=114) \%$ & \\
\hline HIV/AIDS Testing - Total & & & $0.006^{*}$ \\
\hline Yes & 77 & 60.5 & \\
\hline No & 23 & 39.5 & \\
\hline \multicolumn{4}{|c|}{ Source of HIV/AIDS Perceptions } \\
\hline Education based & & & $0.019 *$ \\
\hline Yes & 41.8 & 46.5 & \\
\hline No & 53.3 & 39.5 & \\
\hline Unsure & 4.9 & 14 & \\
\hline Knowledge based & & & 0.084 \\
\hline Yes & 55.7 & 50 & \\
\hline No & 39.3 & 36.8 & \\
\hline Unsure & 4.9 & 13.2 & \\
\hline Church based & & & 0.468 \\
\hline Yes & 21.3 & 20.2 & \\
\hline No & 63.1 & 69.3 & \\
\hline Unsure & 15.6 & 10.5 & \\
\hline HIV Status & & & 0.063 \\
\hline Positive & 9.8 & 5.3 & \\
\hline Negative & 89.3 & 89.5 & \\
\hline Unsure & 0.8 & 5.3 & \\
\hline
\end{tabular}




\begin{tabular}{|c|c|c|c|}
\hline \multirow[b]{3}{*}{ Know someone HIV Positive - Total } & Urban & Rural & $\mathbf{p}$ \\
\hline & $(\mathrm{N}=122) \%$ & $(\mathrm{~N}=114) \%$ & \\
\hline & & & 0.246 \\
\hline Yes & 47.5 & 36.8 & \\
\hline No & 47.5 & 57.9 & \\
\hline Unsure & 4.9 & 5.3 & \\
\hline
\end{tabular}

\section{Recommendations of HIV/AIDS Prevention Programs} Regarding implementation of HIV/AIDS prevention programs within the AA church, the participants were surveyed on the different types of HIV/AIDS programs that should be offered in their church. Prevention programs included: 1) Abstinence (refraining from having sex; 2) condom use; 3) HIV/AIDS prevention and support; 4) HIV/AIDS testing/counseling; and 5) monogamy (having only one sex partner at a time). The participants could choose one program to be implemented in their church. After deciding upon the type of program to be implemented, the participants were surveyed on the different groups (i.e., church leaders, married couples, singles, youth, general congregation) to which the HIV/AIDS program should be oriented. The participants could choose one group that would benefit from the chosen program. As determined by chi-square tests, there were no significant differences among the program recommendations and the groups to which they should be oriented. The urban (36.1\%) and rural (35.8\%) participants were similar in choosing programs to be oriented toward singles and youth as well as the general congregation (urban, $34.1 \%$; rural, $32.1 \%$ ). The urban and rural church participants recommended that HIV/AIDSrelated programs be implemented by the church for each education group (Table 3 ).

Independent sample $t$-test statistical measures were applied to determine if there was a significant difference between urban and rural church participants' HIV/AIDS knowledge based on HIV-KQ scores. The average HIV$\mathrm{KQ}$ score for the participants was 31 of 45 (urban = 31.48; rural $=30.95)$. The standard t-test indicated $t=$ $0.499(\mathrm{p}=0.62)$. The $\mathrm{t}$-test for unequal variances showed $t=0.498(\mathrm{p}=0.62)$ with a $95 \%$ confidence interval $(-$ $1.558,2.614)$. The results show that the difference in mean knowledge scores is not statistically significant and that there is no difference in HIV/AIDS knowledge among urban and rural church participants. Therefore, the null hypothesis is accepted.

Table 3: Urban and Rural HIV/AIDS Prevention Program Recommendations

\begin{tabular}{|l|c|c|c|}
\hline & Urban & Rural & $p$ \\
\cline { 2 - 4 } & $\begin{array}{c}(N=122) \\
\%\end{array}$ & $\begin{array}{c}(N=114) \\
\%\end{array}$ & \\
\hline Church Program Recommendations - Total (\%) & & & 0.414 \\
\hline HIV/AIDS prevention and support & 28.5 & 18.0 & \\
\hline Abstinence & 19.8 & 17.7 & \\
\hline HIV/AIDS testing/counseling & 19.0 & 24.8 & \\
\hline Condom use & 18.2 & 21.5 & \\
\hline Monogamy & 14.5 & 18.0 & \\
\hline Education Group Recommendations - Total & & & 0.412 \\
\hline Singles and youth & 36.1 & 35.8 & \\
\hline General congregation & 34.1 & 32.1 & \\
\hline Church leaders & 15.3 & 16.6 & \\
\hline Married couples & 14.5 & 15.5 & \\
\hline Note: $N$ = Sample size, chi-square, * $=<.05$ & & & \\
\hline
\end{tabular}

Linear regressions were used to determine the extent to which there is a linear relationship between knowledge of HIV/AIDS and geography when controlling for age (in years $)$, gender $(1=$ male, $2=$ female $)$, and education level $(1=$ high school/equivalent, $2=$ some college, $3=$ associates degree, $4=$ bachelors degree, $5=$ 
masters/professional degree, $6=$ doctorate degree). The results indicated that none of these predictors were significantly associated with HIV knowledge. Therefore, these correlations indicated that they would not be significant predictors in the full model. Using the multivariate procedure, the independent variables were entered. The full regression model was as follows:

HIV Knowledge $=$ Age + Gender + Education + Geography
The results of the multiple regression were not significant, $\mathrm{F}(4,231)=0.530(p=0.71)$. The independent variables accounted for $1 \%$ of the variance in HIV Knowledge ( $\mathrm{R}$ square $=0.009)$. The regression results indicate that, when controlling for these factors (age, gender, and education), geography was not a significant predictor of knowledge. Furthermore, the $p$ values indicated that, individually, these variables are not significant predictors of knowledge. Table 4 presents the correlation coefficients and $p$-values for each variable.

\begin{tabular}{|l|c|c|c|c|c|c|}
\hline Table 4. Predictors of Knowledge of HIV/AIDS & & B & SE & Betas & $t$ & $p$ \\
\hline Age & & 0.067 & 0.061 & 0.075 & 1.100 & 0.273 \\
\hline Gender & & -0.673 & 1.08 & -0.042 & -0.626 & 0.532 \\
\hline Education & 0.62 & 0.824 & 0.052 & 0.752 & 0.453 & \\
\hline Geography & 0.441 & 1.07 & 0.027 & 0.413 & 0.680 & \\
\hline Note: $P$ = degree of significance
\end{tabular}

Among the overall sample, 31.8\% had negative perceptions, $58.9 \%$ had positive perceptions, and $9.3 \%$ were unsure of their perceptions of HIV/AIDS testing. The chi-square test was used to assess differences in perceptions of HIV testing among the urban and rural church participants. An unsure response could have indicated a lack of opinion/interest and less exertion of cognitive effort among the urban and rural church participants. The unsure category was not collapsed in order to avoid losing the richness of the data and to understand the relationship between the unsure response and the health belief model construct, a perceived susceptibility/barrier. Table 5 presents the results of this comparison. The data support the research hypothesis and indicate no statistical difference in the percentages of urban and rural respondents who perceived the test positively $\left(X^{2}=1.28, \mathrm{p}=0.53\right)$. There was no statistically significant difference of perceptions of HIV/AIDS testing among the urban and rural AA church participants. The numbers of respondents for each category by location of the church are shown in Table 5.

Point biserial correlation statistics were applied to determine if a correlation existed between knowledge of HIV/AIDS and perceptions of HIV/AIDS testing among the urban and rural church participants. The dependent variables, knowledge of HIV/AIDS (i.e., HIV-KQ total scores) and perceptions of HIV/AIDS testing ( $1=$ Negative, 2 = Positive, 3 = Unsure) were assessed as well as the independent variables of age, gender, education level, marital status $(1=$ married, $2=$ not married, i.e. single, divorced, widow), and church participation (1 = inactive, 2 = barely active, $3=$ fairly active, $4=$ extremely active). The correlation between knowledge of HIV/AIDS and perceptions of HIV/AIDS testing among the participants was not statistically significant $(r=0.078$, $\mathrm{p}=0.233$ ); therefore, the null hypothesis was maintained.

\begin{tabular}{|l|c|c|c|}
\hline Table 5. Urban and Rural - Perceptions of HIV/AIDS Testing \\
\cline { 2 - 4 } & Urban & Rural & $p$ \\
\cline { 2 - 4 } & $\%$ & $\%$ & \\
\hline Perceptions of Testing & & & 0.5 \\
\hline Negative & 28.7 & 35.1 & \\
\hline Positive & 62.3 & 55.3 & \\
\hline Unsure & 9.0 & 9.6 & \\
\hline Note: chi-square test & & & \\
\hline
\end{tabular}

The correlation between church participation and perceptions of HIV/AIDS testing indicated that, as church participation increased, so did perceptions; $r$ (234) = $0.342, \mathrm{p}<0.001$. The $\mathrm{H}_{0}$ is rejected at the $5 \%$ significance level. The correlation between church participation and knowledge of HIV/AIDS indicated an increase in knowledge of HIV/AIDS with an increase in church participation; $r(234)=0.129, p=0.048$. The $\mathrm{H}_{0}$ is rejected at the $5 \%$ significance level. The correlation between gender and perceptions of HIV/AIDS testing 
indicated that gender is involved in the perceptions of HIV/AIDS testing, with females having more positive perceptions; $r(234)=-0.187, p=0.004$. The correlation between HIV knowledge and education indicated that, as education increased, knowledge also increased; $r$ (234) $=$ $0.160, p=0.055$. No other independent variables were statistically significant in relationship as measured by point biserial correlation statistics. Findings for the urban and rural church participants are presented in Table 6 . Significant differences among the urban and rural church participants are noted with an asterisk (*).

\begin{tabular}{|c|c|c|}
\hline & $\begin{array}{c}\text { Urban and } \\
\text { Rural }\end{array}$ & \\
\hline Perceptions and Knowledge & $r$ & $P$ \\
\hline Age and HIV Knowledge & 0.078 & 0.233 \\
\hline Gender and HIV Knowledge & 0.068 & 0.301 \\
\hline Education and HIV Knowledge & -0.041 & 0.534 \\
\hline Marital Status and HIV Knowledge & 0.16 & 0.055 \\
\hline Church Participation and HIV Knowledge & -0.102 & 0.118 \\
\hline Age and Testing Perceptions & 0.129 & $0.048 *$ \\
\hline \multirow[t]{2}{*}{ Gender and Testing Perceptions } & 0.03 & 0.647 \\
\hline & -0.187 & $0.004 *$ \\
\hline
\end{tabular}

\section{DISCUSSION}

Perceptions and knowledge of HIV/AIDS testing among AAs are necessary to decrease the epidemic of HIV. AAs could take a stand against the HIV/AIDS epidemic by decreasing negative perceptions of HIV testing, increasing knowledge of serostatus, and asking pertinent questions about their partner(s) sexual behaviors.

Although this study has indicated high rates of HIV/AIDS testing among the urban church participants, the need for an increase of knowledge of one's serostatus among AAs is still great.

As seen by the lower average HIV/AIDS testing rates among the rural church participants, there is a need for rural AA churches to exert more influence by promoting HIV/AIDS awareness and encouraging routine testing. To implement prevention measures, program evaluations, and resource allocations for HIV/AIDS, AAs must be willing to undergo testing.

Limitations of the study comprise, but are not limited to, the following:

1. Self-reported data were collected from the participants.

2. Participation was voluntary.

3. The data obtained may not be generalizable to other races; nevertheless, this evaluative methodology may be modified for other AA churches.

4. Research findings may be subject to social bias due to the sensitive nature of the topic.

5. Participants may have displayed recall bias in regard to providing information on their previous behaviors.

\section{Implications for Public Health}

Researchers and public health advocates are intrigued by the role the AA church plays in promoting health awareness, HIV/AIDS prevention, and behavioral change. These churches have been central in the lives of many AAs and have shaped cultural norms and attitudes. However, raising awareness about the epidemic of HIV/AIDS has become a challenge, with few open discussions and low community support. Although this study did not examine the role of the AA church, the literature and the results of this study indicate a need to examine its role in increasing HIV/AIDS testing rates among AA church members. Many individuals are prone to behavioral change if they belong to a strong support system.

To bring change among this population, a partnership between AA churches, faith-based organizations, community stakeholders, public health practitioners, and legislators should be established. The establishment of this type of relationship may have a great impact on the perceptions of HIV/AIDS testing, which may allow for federal funds to be utilized to increase quality and access to health care facilities for this population. Although this study indicated positive perceptions and average-to-high rates of HIV/AIDS testing, a partnership of this sort may dispel negative perceptions or fears associated with not trusting healthcare providers and in turn lead to better care, more treatment options, and the establishment of a primary healthcare provider compared to an emergency room visit. Nevertheless, social change can begin with support to the individual from the church, the community, and other stakeholders. 


\section{References}

Adedeji, A., Titilayo, T., Joseph, B., \& Mainza Lukobo-Durrell. (2009). HIV Sexual Risk Behaviors and Perception of Risk Among College Students: Implications for Planning Interventions. BMC Public Health. 2009;9:281.

Billingsley, A. (1992). Climbing Jacob's ladder: The enduring legacy of African-American families. New York: Simon and Schuster.

Centers for Disease Control and Prevention (CDC). (2012). Estimated HIV incidence among adults and adolescents in the United States, 2007-2010. HIV Surveillance Supplemental Report 2012;17(4).

Centers for Disease Control and Prevention. (2015a). HIV Basic Statistics. Retrieved online from: http://www.cdc.gov/hiv/statistics/basics.html

Centers for Disease Control and Prevention. (2015b). CDC Fact Sheet. HIV among African Americans. Retrieved online from: http://www.cdc.gov/nchhstp/newsroom/docs/CDC-HIV-AA$\underline{508 . p d f}$

Coleman, C. (2003). Spirituality and sexual orientation: relationship to mental well-being and functional health status. Journal of Advanced Nursing, 43, 457-464. doi:10.1046/j.1365-2648.2003.02743.x

Daniels, P., \& Wimberly, Y. (2004). HIV testing rates among African Americans: Why are they not increasing? Journal of the National Medical Association, 96(8), 1107-1108.

Hall, H.I., An, Q, Hutchinson, A.B., \& Sansom, S. (2008). Estimating the lifetime risk of a diagnosis of the human immunodeficiency virus (HIV) infection in 33 states, $2004-$ 2005. Journal of Acquired Immune Deficiency Syndrome, 49, 294-297. doi:10.1097/QAI.0b013e3181893f17

Krakauer, M., Phil, M., \& Newberry, J. (2007). Churches' responses to HIV/AIDS in two South African communities. Journal of the International Association of Physicians in AIDS Care, 6, 27-35. doi:10.1177/1545109706297551
Levine, R. (2007). Case studies in global health: Millions saved. Sudbury, MA: Jones and Bartlett Publishers.

McKoy, J., \& Peterson, R. (2006). Reducing African-American women's sexual risk: Can churches play a role? Journal of the National Medical Association, 98, 1151-1159.

Moore, J. (2003). A symposium - global ethics on HIV/AIDS: Perspectives from the religions and the sciences. Zygon, 38, 121-124. doi:10.1111/1467-9744.00485

National Institute of Allergy and Infectious Diseases. (2009). Testing and diagnosis: Routine HIV testing. Retrieved from http://www.niaid.nih.gov/topics/HIV/AIDS/Understanding/Pa ges/diagnosis.aspxNational Institute of Allergy and Infectious Diseases. (2010). National Black HIV/AIDS Awareness Day. Retrieved from http://www.niaid.nih.gov/news/newsreleases/Archive/2010/Pa ges/BAAID10.aspx

National Institute of Medicine (NIH) Medline Plus. (2009). The Nation's Top HIV/AIDS Researcher Discusses This Continuing Health Threat. Retrieved online from: http://www.nlm.nih.gov/medlineplus/magazine/issues/summe r09/articles/summer09pg11-13.html

Nunn, A., Cornwall, A., Thomas, G., Waller, A., Friend, R., Broadnax, J., and Flanigan, T. (2013). What's God got to do with it? Engaging African American faith based institutions in HIV prevention. Glob Public Health; 8(3): 258-269. doi:10.1080/17441692.2012.759608.

Whitmore, S., Satcher, A., \& Hu, S. (2005). Epidemiology of HIV/AIDS among non-Hispanic black women in the United States. Journal of the National Medical Association, 97, 19S24S.

Williams, F.L. (1972). Richard Allen and Mother Bethel African Methodist Episcopal Church. Philadelphia: Historical Commission on Mother Bethel AME Church. 